\title{
PROSTYTUCJA JAKO CZYNNOŚĆ NIEPODLEGAJĄCA OPODATKOWANIU W PRAWIE POLSKIM
}

\begin{abstract}
Streszczenie. Celem publikacji jest przybliżenie unormowań prawnych odnoszących się do wielokrotnie przedstawianego przez sądy administracyjne i organy podatkowe poglądu, zgodnie z którym prostytucja jest czynnością, która nie może być przedmiotem prawnie skutecznej umowy i jako taka nie podlega opodatkowaniu w prawie polskim. W pierwszej części tekstu opisane zostało stanowisko wyrażane w tym zakresie w toku wykładni operatywnej. W drugiej części skupiono się na ustawowej podstawie wyłączenia, wskazano jej związek z sądami o charakterze moralnym. W tym fragmencie omówiono również istotne z punktu widzenia toczonych rozważań interpretacje indywidualne Ministra Finansów. Dalszy wywód poświęcony jest stricte moralnemu wymiarowi prostytucji; autor przedstawia możliwe sposoby argumentacji popierającej potępienie nierządu oraz racje im przeciwne. Ostatnia część artykułu dotyczy praktyki postępowań i ustaleń czynionych przez organy podatkowe w sprawach dotyczących prostytucji.
\end{abstract}

Słowa kluczowe: prostytucja, nierząd, podatek, interpretacja indywidualna, moralność, skuteczność czynności prawnej.

\section{WYKAZ SKRÓTÓW}

k.c. - ustawa z dnia 23 kwietnia 1964 r. - Kodeks cywilny (t.j. Dz. U. 2017, poz. 459 ze zm.).

o.p. - ustawa z dnia 29 sierpnia 1997 r. - Ordynacja podatkowa (t.j. Dz. U. 2015, poz. 613 ze zm.). u.p.d.o.f. - ustawa z dnia 26 lipca 1991 r. o podatku dochodowym od osób fizycznych (t.j. Dz. U. 2017, poz. 859 ze zm.).

ustawa o VAT - ustawa z dnia 11 marca 2004 r. o podatku od towarów i usług (t.j. Dz. U. 2017, poz. 379 ze zm.).

\section{WPROWADZENIE}

W dniu 13 kwietnia 2015 r. Dyrektor Izby Skarbowej w Katowicach (działający w imieniu Ministra Finansów) wydał interpretację indywidualną przepisów prawa podatkowego w zakresie podatku dochodowego od osób fizycznych (IBPBII/1/4511-86/15/ASz), której przyszło zmierzyć się z odzewem

* Uniwersytet Łódzki, Wydział Prawa i Administracji, Katedra Teorii i Filozofii Prawa, adam.tomasz.olczyk@gmail.com. 
niespotykanym często $\mathrm{w}$ tej gałęzi prawa. Media inne niźli stricte prawnicze nie tylko rzadko interesują się ustaleniem granic niezwykle pojemnego pojęcia przychodu, lecz cała w ogóle sfera świata podatków z przyczyn oczywistych spotyka się z zainteresowaniem, które nie może się równać z uwagą jaką poświęca się rozpalającym wyobraźnię zbrodniom czy kontrowersyjnym orzeczeniom przesądzającym o wysokim odszkodowaniu bądź zadośćuczynieniu. Swoją popularność wspomniana interpretacja zawdzięczała temu, że zahaczała o tabu, które w naszej kulturze wciąż utrzymuje się nie najgorzej - sferę, o której nieco staroświecko można powiedzieć, że dotyczy tzw. aktów miłosnych. I choć oczywiście nie sposób nie zauważyć, że w minionym wieku doszło w tej dziedzinie do pewnego ewidentnego rozluźnienia napięć, którym wcześniej przez tysiące lat udawało się zachować względnie podobny stopień intensyfikacji, to jednak w pokaźnej części współczesnej rzeczywistości społecznej seksualność wciąż owiana jest magiczną aurą sacrum. Tym samym połączenie owego tabu z dziedzina, która kojarzy się z obszarem dominacji władzy państwowej (i to szczególnie sformalizowanym), wywołuje poruszenie, któremu trudno się dziwić. Zespolenie tego, o czym mówić zazwyczaj nie wypada, z tym, o czym rozmawiać przeważnie nie lubimy i bez czego chętnie byśmy się obeszli, stanowi wszak kompozycję co najmniej intrygująca.

We wskazanej interpretacji organ uznał, że przychody z uprawiania nierządu można traktować jako dochody „wolne od opodatkowania”. W konsekwencji powstawały artykuły o przyciagających uwagę tytułach: PIT: prostytucja pomoże „wywinać się” z nieujawnionych przychodów (Malinowski 2015), Polska prostytutka wygrała z fiskusem. Pokazała zdjęcia, cennik, recenzje i uratowała oszczędności z 9 lat (Molga 2015), Prostytucja sposobem na uniknięcie ptacenia podatków (Kuc 2015), Prostytucja sposobem na legalizację pieniędzy (Pogroszewska 2015). $\mathrm{Z}$ tekstów tych wyłaniał się wniosek, w zgodzie z którym interpretacja miała charakter precedensowy i otwierała nową ścieżkę dla wszystkich tych, którzy starają się uniknąć sankcyjnej stawki przewidzianej dla przychodów nieznajdujących pokrycia w ujawnionych źródłach lub pochodzących ze źródeł nieujawnionych (wynoszącej aż $75 \%$ podstawy opodatkowania). Nie zwracano przy tym szczególnej uwagi na to, że omawiana kwestia była w orzecznictwie sądów administracyjnych w Polsce jednoznacznie oceniana i nie wywoływała szczególnych kontrowersji. W licznych komentarzach pod artykułami oraz na internetowych forach podatnicy wymieniali się natomiast radami, jak wykorzystać nowe narzędzie, w które wyposażył ich omawiany akt ministra, tj. jak przechytrzyć system podatkowy i w jaki sposób uniknąc płacenia podatku dochodowego.

Nie umniejszając w żaden sposób wymogowi dawania wiary oświadczeniom podatnika składanym przed organami administracji, podnieść trzeba, że obecne jest i było w naszym kraju przekonanie, iż powołanie się na uzyskiwanie przychodu tytułem nierządu jest jedną ze skuteczniejszych metod wymanewrowania państwa w zakresie, w jakim sięga ono po zarobki, od których nie zapłacono 
należnego podatku. Omawiana interpretacja pełniła nie tylko funkcję edukacyjną, to jest nie tylko zapoznawała podatników z treścią obowiązującej regulacji prawnej; jej znaczenia dopatrywać należy się także (a może zwłaszcza) w potwierdzeniu swoim autorytetem, prestiżem wykładni operatywnej, prawidłowości takiego rozumienia przepisów. Lektura dyskusji toczonych w Internecie prowadzi do mało kontrowersyjnego wniosku, że pracownicy organów są świadomi tego, iż powołanie się na nierząd jest niejednokrotnie niczym innym niźli ukrywaniem dochodu. Podatnicy opisują jakie ustalenia są podejmowane w konsekwencji wskazania na prostytucję jako źródło przychodu i jak skutecznie brnąć w wyjaśnieniach. Sprawy takie są prowadzone bowiem szczególnie wnikliwie. Nie bardzo to dziwi w kontekście spostrzeżenia, iż na internetowych forach odnaleźć można również dyskusje, w których to pracownicy organów, w odpowiedzi na działania podatników, szczegółowo wymieniają się swoimi doświadczeniami, udzielając sobie wzajem wnikliwych porad co do najlepszego sposobu ustalenia jak najdokładniejszego obrazu stanu faktycznego w takich przypadkach.

W niniejszym tekście postaram się omówić ustawową podstawę dotyczącą omawianego zwolnienia. W tym celu w pierwszej kolejności przedstawię (pkt 2) poglądy, jakie w przedmiotowym zakresie były wyrażane przez sądy oraz organy administracji. Następnie odniosę się do (pkt 3) regulacji prawnej, zestawiając ją ze wskazaną wyżej interpretacją indywidualną oraz interpretacjami dotyczącymi tzw. wirtualnej prostytucji. Kolejno wskażę racje przemawiające za potępieniem nierządu (pkt 4): w pierwszej kolejności o charakterze stricte moralnym, w drugiej - bliższe prawnemu aspektowi, takie, które można by powoływać w podobnych sprawach. Na koniec zaprezentuję (pkt 5) przykłady problemów praktycznych, z jakimi mogą mierzyć się urzędnicy w sytuacji, gdy podatnik powołuje się na zyski z nierządu. Wywód ten ma przy tym spełnić dwa zadania. Po pierwsze, potwierdzić słuszność dominującego obecnie stanowiska. Po drugie - co istotniejsze - pogłębić zakres podejmowanej refleksji, uzasadnić wyrażane poglądy i zaznaczyć ewentualne kwestie sporne, które mogą się zarysować.

Wypada jeszcze uprzedzić, że wzorem praktyki orzeczniczej, w niniejszym tekście uznaję pojęcie „nierządu” za tożsame z terminem „prostytucja” i stosuję je zamiennie.

\section{STANOWISKO SĄDÓW ADMINISTRACYJNYCH I ORGANÓW PODATKOWYCH}

Jak wskazano wyżej, lektura istotnej części artykułów, które pojawiły się po wydaniu interpretacji z dnia 13 kwietnia 2015 r. mogła wywołać wrażenie, że rozstrzygnięcie Dyrektora Izby Skarbowej w Katowicach miało precedensowy charakter. Tymczasem pogląd, że przychody z uprawiania nierządu nie podlegają opodatkowaniu podatkiem dochodowym od osób fizycznych przez lata wyrażany 
był zarówno w decyzjach organów podatkowych, jak i w orzeczeniach sądowych. Nieznacznie wyprzedzając tok wywodu, należy odnotować, że jego podstawę stanowi art. 2 ust. 1 pkt 4) u.p.d.o.f., zgodnie z którym przepisów tej ustawy nie stosuje się do przychodów wynikających z czynności, które nie mogą być przedmiotem prawnie skutecznej umowy (do dnia 1 stycznia 1992 r. tożsama norma wyrażona była w punkcie 3 ust. 2 omawianego przepisu).

I tak, już z treści wyroku Naczelnego Sądu Administracyjnego, Ośrodek Zamiejscowy w Gdańsku, z dnia 7 kwietnia 1995 r., sygn. akt SA/Gd 57/95, wynika, że organy właściwe w sprawie w przedmiocie podatku dochodowego za $1992 \mathrm{r}$. nie kontestowały twierdzenia, zgodnie z którym powołanie się na ,świadczenie stałym partnerom usług towarzysko-seksualnych" prowadzi do uniknięcia obowiązku podatkowego, a to właśnie ze względu na to, że źródło przychodów stanowiły czynności, które nie mogą być przedmiotem prawnie skutecznej umowy. W dalszej części uzasadnienia tego orzeczenia pogląd ten został zaaprobowany przez skład orzekający.

Tożsame zapatrywanie wyraził tenże sąd w wyroku z dnia 8 maja 1996 r., sygn. akt SA/Gd 675/95, uznając, że płatne kontakty intymne nie stanowią podstawy do opodatkowania podatkiem dochodowym, co wyraźnie wynika z treści art. 2 ust. 1 pkt 3 u.p.d.o.f. (sprawa dotyczyła podatku za 1991 r.). Co warte odnotowania, NSA podniósł przy okazji, że prostytucja nie podlegała opodatkowaniu także pod rządem ustawy z dnia 16 grudnia 1972 r. o podatku dochodowym. Wniosek ten sąd wyprowadził $\mathrm{z}$ art. 6 ust. $1 \mathrm{i}$ art. 7 ust. 8 tejże regulacji, tj. na podstawie przepisów, które wymieniały, co należy zaliczyć do kategorii źródeł przychodów. Choć kwestia ta nie została rozwinięta, sąd rozumował zapewne a contrario - wskazane artykuły nie przewidywały takiej kategorii źródeł przychodów, które można byłoby łączyć z zyskami uzyskiwanymi poprzez nierząd.

Istotne znaczenie dla omawianej materii ma wyrok wydany przez Naczelny Sąd Administracyjny, Ośrodek Zamiejscowy w Gdańsku, z dnia 3 lutego 2000 r., sygn. akt I SA/Gd 1011/99, w którym wprost zawarto stwierdzenie, iż za słuszne uznać należy zakwalifikowanie przychodów z prostytucji do przychodów z art. 2 ust. 1 pkt 4) u.p.d.o.f. Jego rola jest o tyle istotna, że sądy administracyjne niejednokrotnie powoływały się na treść tego orzeczenia w sprawach dotyczących opodatkowania prostytucji (tak choćby Wojewódzki Sąd Administracyjny w Poznaniu w wyrokach z dnia 3 lutego 2005 r., sygn. akt I SA/Po 2189/03; z dnia 17 marca 2005 r., sygn. akt I SA/Po 134/03; z dnia 25 stycznia 2007 r., sygn. akt I SA/Po 691/06; Wojewódzki Sąd Administracyjny w Gdańsku z wyroku z dnia 10 października 2006 r., sygn. akt I SA/Gd 599/05; Wojewódzki Sąd Administracyjny w Łodzi w wyroku z dnia 7 maja 2007 r., sygn. akt I SA/Łd 2005/06; Naczelny Sąd Administracyjny w wyroku z dnia 29 lipca 2008 r., sygn. akt II FSK 727/07).

Wyrok ten jest symptomatyczny z jeszcze jednego powodu. Otóż, NSA poprzedził swoją ocenę zwróceniem uwagi na okoliczność, że chociaż takie zakwalifikowanie przychodów z prostytucji jest bezsporne, to organy powstrzymały się 
od wyraźnej wypowiedzi w tym zakresie. Niechęć organów do przyznania, że prostytucja nie podlega podatkowi dochodowemu przejawia się w treści orzeczeń sądowych, zaś chyba najbardziej dosadnym tego przykładem jest postępowanie w sprawie zakończonej wyrokiem Wojewódzkiego Sądu Administracyjnego w Gorzowie Wielkopolskim z dnia 8 listopada 2005 r., sygn. akt I SA/Go 723/05. O ile bowiem organy często ograniczają się do pomijania przedmiotowej kwestii, o tyle z uzasadnienia wskazanego wyroku wynika, że Dyrektor Izby Skarbowej wyraził w decyzji stanowisko, w myśl którego wyłączone spod działania ustawy o podatku dochodowym od osób fizycznych są te przychody, których uzyskanie skutkuje sankcjami przewidzianymi w prawie karnym, dopuszczalne zaś jest opodatkowanie podatkiem dochodowym czynności, które są sprzeczne z zasadami współżycia społecznego, jak np. prostytucja. Tym samym bezpośrednio wystąpił naprzeciw niespecjalnie kontrowersyjnego stanowiska wyrażanego w orzecznictwie i doktrynie. Nadmienić można, że w sprawie tej organ drugiej instancji zmienił swoje zapatrywanie w tym zakresie w odpowiedzi na skarge - zachowanie to jest znamienne, gdy wziąć pod uwagę praktykę formułowania odpowiedzi na skargę w przypadku uznania jej zarzutów (a tak było w tej sprawie) za bezzasadne; ta polega bowiem najczęściej na podtrzymywaniu stanowiska wyrażonego w decyzji i utrzymaniu przedstawionej tam argumentacji.

O niechęci organów do formułowania wypowiedzi równie kategorycznych, co zawarty w omawianym wyroku osąd: „,bez wątpienia należy zaznaczyć, że stanowisko organów obu instancji wyrażone w decyzjach, iż przychody z prostytucji podlegają ustawie o podatku dochodowym od osób fizycznych nie jest zgodne z prawem", świadczy także tok postępowania poprzedzający wydanie głośnej interpretacji z 2015 r. Zanim Dyrektor Izby Skarbowej w Katowicach przedstawił swoje zapatrywanie, w dniu 3 stycznia 2014 r. wydał postanowienie o odmowie wszczęcia postępowania, a to dlatego, że poruszone we wniosku zagadnienia miały wykraczać poza zakres kompetencji organu interpretacyjnego. Uznano, że $\mathrm{w}$ istocie wnioskodawczyni nie chodziło o dokonanie interpretacji budzących wattpliwości przepisów prawnych, ale o ocenę wskazanych przez nią dowodów. Wyrokiem z dnia 10 września 2014 r., sygn. akt I SA/Kr 1009/14, Wojewódzki Sąd Administracyjny w Krakowie uchylił to postanowienie, podnosząc, że pytanie w brzmieniu: „czy środki pieniężne na pokrycie wydatków wnioskodawcy na zakup nieruchomości mogą podlegać opodatkowaniu jako nieujawnione źródła przychodu stawką 75\%, jeżeli zostały uzyskane z uprawiania nierządu?", nie odwołuje się do konieczności oceny, czy skarżąca faktycznie uzyskała dochody z nierządu i nie było żadnych prawnych przeciwwskazań, aby wydać interpretację w tym zakresie.

Zwrócić jeszcze można uwagę na postanowienie w sprawie interpretacji prawa podatkowego z dnia 11 maja 2007 r., wydane przez Urząd Skarbowy w Skarżysku-Kamiennej (nr DP/415-10/07). Wskazując na art. 2 ust. 1 pkt 4) u.p.d.o.f., organ stwierdził w nim, że ,środki pieniężne otrzymywane z tytułu uprawiania 
nierządu-prostytucji w Polsce nie pochodzą ze źródeł przychodów opodatkowanych, bądź wolnych od opodatkowania, nie mieszczą się w źródłach przychodu zawartych w art. 10 powołanej ustawy podatkowej”. Podniesiono przy tym także, iż ustawa o podatku dochodowym od osób fizycznych nie ma zastosowania do przychodów z prostytucji, a tym samym zeznanie podatkowe nie obejmuje przychodów z prostytucji, zaś nie składając zeznania o przychodach z uprawiania prostytucji, nie popełnia się przestępstwa ani wykroczenia skarbowego. Organ podkreślił, że karze nie podlega niezłożenie zeznania o przychodach z uprawiania prostytucji, gdyż przepisy ustawy podatkowej nie mają zastosowania $\mathrm{w}$ tej materii. Postanowienie to potwierdza więc schemat argumentacyjny przyjęty $\mathrm{w}$ orzecznictwie i doktrynie.

\section{PROSTYTUCJA JAKO CZYNNOŚĆ, KTÓRA NIE MOŻE BYĆ PRZEDMIOTEM PRAWNIE SKUTECZNEJ UMOWY}

\subsection{Ustawowa podstawa wyłączenia}

Przytoczone przykłady świadczą o tym, że jednoznacznie przyjmuje się, iż to art. 2 ust. 1 pkt 4) u.p.d.o.f. stanowi podstawę omawianego wyłączenia. Regulację analogiczną zawiera art. 6 pkt 2 ustawy o VAT. W jego myśl ustawy tej nie stosuje się do czynności, które nie mogą być przedmiotem prawnie skutecznej umowy. W licznych komentarzach do tych artykułów prawie zawsze prostytucja pojawia się jako jeden z przykładów. Różnica między nimi polega na tym, że w przypadku podatku dochodowego ustawodawca uściślił, iż chodzi o „przychody wynikające” z przedmiotowych czynności, gdy w ustawie o VAT dyspozycją objęto bezpośrednio same czynności. Odrębność ta pozostaje bez wpływu na treść podejmowanych tutaj kwestii. Rozważania skupiają się bowiem na uznaniu nierządu za określoną czynność - taką, która nie może być przedmiotem prawnie skutecznej umowy; abstrahują więc od tego, czy przychód z nich wynika i są niezależne od ustalenia różnic między treścią obu przepisów. Regulacja ustawy o VAT jest istotna ze względu na uwagi, jakie zostaną przedstawione dalej w kontekście tzw. „wirtualnej prostytucji".

Sformułowanie „czynności, które nie mogą być przedmiotem prawnie skutecznej umowy" zazwyczaj łączy się z rozróżnieniem dwóch płaszczyzn: empirycznej i normatywnej (tak m.in. Naczelny Sąd Administracyjny w wyroku z dnia 15 stycznia 2008 r., sygn. akt II FSK 1578/06). Pierwsza odnosi się do zachowań, które ze swojej istoty są sprzeczne z prawami przyrody, oczywiście nie może więc dotyczyć prostytucji. Drugi obszar, normatywny należy łączyć ze sferą prawną oraz szeroko rozumianą moralnością (Strzelec 2014, 54). Wskazuje się przy tym, iż opodatkowaniu nie będą podlegały te przychody, które wynikają z czynności, które naruszają którykolwiek z tych porządków. Katalog egzemplifikacji kategorii 
prawnej jest tyleż szeroki, co powtarzalne są jego elementy, przedstawiane w licznych opracowaniach. Zwyczajowo wymienia się tutaj m.in. stręczycielstwo, handel narkotykami, łapówkarstwo czy płatną protekcję (Krywan 2014, 87). Zasadność takiej regulacji wydaje się oczywista - jest zgodne z elementarną intuicją moralno-prawną przeciętnego obywatela przekonanie, że państwo nie może (nie powinno) czerpać korzyści z porozumienia, którego treść występuje naprzeciw ładowi prawnemu i moralnemu. Trudno sobie wyobrazić np. sytuację, w której suweren domaga się podatku od umowy, jaką płatny zabójca zawiera ze swoim zleceniodawca.

\subsection{Moralny aspekt czynności}

Kwestia sprzeczności czynności z normami moralnymi ma oczywiście bardziej skomplikowany charakter. Dziś, w dobie pooświeceniowego paradygmatu, który wychodzi naprzeciw światopoglądowemu monizmowi; paradygmatu, który uznaje, że między prawidłowymi odpowiedziami na najważniejsze problemy życia może zachodzić sprzeczność (Berlin 2004, 7), wskazane jest, by mówiąc o moralności, dookreślić, iż w omawianym kontekście chodzi o te przekonania, które są ogólnie dzielone w danym społeczeństwie.

Ujawnia się przy tym zaznaczany w piśmiennictwie związek, jaki łączy art. 2 ust. 1 pkt 4) u.p.d.o.f. z regulacją prawa cywilnego, zwłaszcza z art. $58 \S 1$ i $~ 2$ oraz art. $353^{1}$ k.c. Uzasadniając właściwość takiego odniesienia, tj. skorzystania $\mathrm{w}$ toku postępowania administracyjnego $\mathrm{z}$ dorobku innej gałęzi prawa, wskazuje się w pierwszej kolejności na cywilistyczną terminologię, z jakiej korzysta ustawa podatkowa w przedmiotowym zakresie (czynność, przedmiot umowy, jej prawna skuteczność), w drugiej - zwraca się uwagę na to, że ograniczenie zasady swobody umów czy w ogóle zdolności bycia przedmiotem stosunku cywilnoprawnego, niewątpliwie związane z omawianym wyłączeniem, wynika właśnie ze wskazanych przepisów Kodeksu cywilnego. Zgodnie z poglądami doktryny i orzecznictwa, a także praktyką urzędnicza, stwierdzić trzeba, że niezależnie od tego, czy za podstawę przyjąć art. $58 \S 1 \mathrm{i} \S 2$, czy art. $353^{1}$ k.c., przesłanka, która wyłącza stosowanie przepisów ustawy o podatku dochodowym od osób fizycznych do przychodów wynikających z prostytucji, odsyła do tego samego obwarowania, do bodaj najistotniejszej klauzuli generalnej w całym polskim porządku prawnym - zasad współżycia społecznego.

Tak więc, analizując art. 2 ust. 1 pkt 4) u.p.d.o.f., bierze się pod uwagę aspekt moralny czynności, mając jednak na uwadze, że nie chodzi tu tylko o powszechnie dzielone w społeczeństwie przekonania, ale i dorobek cywilistyki polskiej w tym wymiarze, w jakim odwołuje się on do zasad współżycia społecznego. Zbigniew Radwański mówi o wartościach stanowiących dziedzictwo i składnik kultury europejskiej, które są powszechnie uznane w kulturze społeczeństwa (Radwański 2004, 39). Charakter stosunku, w jakim pozostają zasady współżycia 
społecznego do norm moralnych, sporny w doktrynie (Pietrzykowski 2015, 51), nie ma dla przedstawionego tutaj wywodu szczególnego znaczenia - wystarczające jest uwzględnienie istotności zachodzącej między nimi korelacji.

\subsection{Interpretacja indywidualna $\mathrm{z}$ dnia 13 kwietnia $2015 \mathrm{r}$.}

Wydaje się, że taki też tok rozumowania przyjął organ wydający interpretację z 2015 r. Przedstawione przez Dyrektora Izby Skarbowej w Katowicach rozważania cechuje jednak znaczna ogólnikowość, która skutecznie pozbawia teoretyków materiału, z jakim można by wejść w rzetelną polemikę. W istocie, analiza interpretacji nie pozwala nawet stwierdzić z całkowitą pewnością, czy faktycznie organowi chodziło o to, że prostytucja jest sprzeczna z zasadami współżycia społecznego - choć pogląd taki wydaje się najbardziej prawdopodobny. W imieniu Ministra Finansów przedstawiono bowiem następujący tok argumentacyjny: (1) najpierw odniesiono się do regulacji art. 2 ust. 1 pkt 4) u.p.d.o.f., krótko ją wyjaśniając; (2) następnie wskazano na art. 58 § 1 i $\S 2$ k.c., eksplikując ich związek z poprzednim przepisem; (3) dalej zaprezentowano przepisy o przychodach nieznajdujących pokrycia w ujawnionych źródłach lub pochodzących ze źródeł nieujawnionych, by końcowo, (4) po skrótowym powtórzeniu zdarzenia przyszłego opisanego we wniosku, rozstrzygnąć: „Mając powyższe na względzie, stwierdzić należy, że czynności wykonywane przez Wnioskodawczynię nie mogą być przedmiotem prawnie skutecznej umowy. Tym samym nie mogą również podlegać opodatkowaniu podatkiem dochodowym od osób fizycznych, co wynika z art. 2 ust. 1 pkt 4 ustawy o podatku dochodowym od osób fizycznych. W konsekwencji przychody z uprawiania nierządu mogą być traktowane jako dochody »wolne od opodatkowania «".

Nie wiadomo, czym jest „powyższe”, gdyż w całej interpretacji brak podstawowego wnioskowania, które bezpośrednio przystawiałoby prostytucję bądź to do zasad współżycia społecznego, bądź innej z przesłanek art. 58 k.c., czy też w jeszcze inny sposób łączyłoby to zjawisko z regulacją art. 2 ust. 1 pkt 4) u.p.d.o.f. Niechęć, o której mowa była wcześniej, idzie więc dalej: interpretacja pozbawiona jest wywodu i argumentacji, jakie mogliby cytować inni podatnicy. Na podobne braki cierpi wskazane wcześniej postanowienie z dnia 11 maja 2007 r., wydane przez Urząd Skarbowy w Skarżysku-Kamiennej.

Przyczyna jest oczywista - chodzi o szczególnego rodzaju prewencję, wychodzącą naprzeciw szkodliwej praktyce, którą mogłyby podjudzać nazbyt stanowcze zwroty. Nie można tu jednak pominać tego, że także sądy administracyjne nie wchodzą w szczegóły w podobnych przypadkach. Zjawisko prostytucji i w tym wymiarze kroczy ścieżką, która od wieków wyznacza jego koleje w ogóle, jawiąc się jako przemilczane zło konieczne, którego wyrugować ze świata nie sposób; każdy zaś sprzeciw w tym zakresie wiązać trzeba czy to z typowym dla fanatyków brakiem poczucia konieczności zachowania koherencji głoszonych poglądów z rzeczywistością społeczną, czy to z młodzieńczą naiwnością. 
Należy jednak powstrzymać się przed pochopną oceną owych przemilczeń, nie jest wszak ambicją autora uzasadnienia, powstałego na podstawie analizy przepisów prawnych, konkurować z dywagacjami etyków i filozofów; teksty te pełnią zupełnie inne role. Mimo to można naszkicować ewentualne problemy, jakie jawić się mogą w związku z uznaniem prostytucji za czynność, która z racji tego, że godzi w zasady rządzące współżyciem społecznym, nie może być przedmiotem prawnie skutecznej umowy.

\subsection{Interpretacje indywidualne w sprawach tzw. wirtualnej prostytucji}

Omawiane kwestie szczególnie zyskują na znaczeniu wobec dwóch indywidualnych interpretacji prawa podatkowego wydanych przez Dyrektora Izby Skarbowej w Katowicach w dniu 7 stycznia 2015 r. w związku z tzw. wirtualną prostytucją (pierwsza - IBPBI/1/415-1164/14/AP, druga - IBPP2/443-987/14/IK). W obu sprawach przedstawiony został właściwie tożsamy opis zdarzenia przyszłego. Wnioskodawczyni wyjaśniła, że trudni się tzw. „wirtualną prostytucją”, co oznacza, że przy użyciu internetowej kamery łączy się z klientem, który na bieżąco kieruje jej postępowaniem, nakierowanym na zaspokojenie popędu seksualnego. W pierwszej ze spraw zapytano o generowanie przychodów podlegających opodatkowaniu podatkiem dochodowym od osób fizycznych, czyli dotyczyła ona art. 2 ust. 1 pkt 4) u.p.d.o.f.), w drugiej - o to, czy uzyskany przychód nie rodzi obowiązków podatkowych w podatku od towarów i usług. Tutaj podstawą był art. 6 pkt 2 ustawy o VAT. Tym samym, wobec nieistotnych różnic w konstrukcji obu przepisów, uznać trzeba, że sporne zagadnienie było praktycznie tożsame.

Zarówno opis stanu faktycznego przedstawiony we wniosku o wydanie interpretacji, jak i konsekwencje, jakie z nim wiązano, były analogiczne. W przeprowadzonych wywodach skupiono się na kwestii przekonania organu do tego, że opisane czynności seksualne, dokonywane przy użyciu internetowej kamerki, można zakwalifikować jako prostytucję. Wnioskodawczyni właściwie domniemywała, że prostytucja jest nieopodatkowana; choć nie można powiedzieć, że rozważań w tym kontekście w ogóle nie czyniła, miały one jednak charakter zdawkowy. Wśród przedstawionych argumentów wskazać można na ten, że także kobiety, które „spotykają się realnie z klientami, oferując seks usługi, nie zawsze uprawiają normalny fizyczny seks z każdym klientem"; w jego ramach podano też przykłady takich zachowań (IBPBI/1/415-1164/14/AP). Odpowiedź Dyrektora Izby Skarbowej w Katowicach w obu przypadkach była negatywna, tzn. uznawała stanowisko przedstawione we wniosku za nieprawidłowe. Co ciekawe, mimo że przesłanki wyłączenia obu czynności spod opodatkowania były analogiczne, argumentacja w obu przypadkach była różna.

I tak, w interpretacji wydanej w zakresie podatku dochodowego od osób fizycznych organ podzielił niejako schemat rozumowania wnioskodawczyni, również uznając za kluczową kwestię ustalenia, czy opisane czynności można 
zakwalifikować jako prostytucję. Udzielona odpowiedź przeciwstawiała się jednak tej przedstawionej we wniosku. Organ położył nacisk na aspekt kontaktu fizycznego, którego brak w przypadku internetowego nierządu, co wykluczać ma sposobność skorzystania ze zwolnienia. W końcowej części interpretacji wskazano natomiast, że opisane czynności raczej należy kojarzyć z pornografią.

W drugim akcie Dyrektor Izby Skarbowej również zaakcentował brak fizycznego aspektu działalności (oddanie własnego ciała do dyspozycji innych osób), co uniemożliwiało uznanie czynności seksualnych podejmowanych w cyberprzestrzeni za nierząd. Jednakże - niewątpliwie zasadnie - organ na tym nie poprzestał, mając na uwadze, iż właściwą przesłanką jest to, by czynność nie mogła być przedmiotem prawnie skutecznej umowy, zaś ograniczenie się do kwestii kwalifikacji wirtualnej prostytucji jako nie-prostytucji jest oczywiście niewystarczające. Przedstawiony dalej w interpretacji wywód jest o tyle ciekawy, że organ ponownie porusza kwestię nierządu per se, by - posiłkując się literaturą - wyrazić precedensową tezę: „w odniesieniu do umowy z prostytutką nie musi zachodzić sprzeczność z zasadami współżycia społecznego" (tym samym, a maiori ad minus, sprzeczność taka nie jest konieczna w przypadku czynności podejmowanych przez Internet). Pogląd ten poparty zostaje uwagami związanymi z orzecznictwem Trybunału Sprawiedliwości Unii Europejskiej, które dla niniejszego tekstu nie mają jednak szczególnego znaczenia.

Niewątpliwie zajmująca kwestia relacji między nierządem w ogóle a wirtualną prostytucją oraz ustalenie, czy ta druga winna być zwolniona z podatku ze względu na omawiane przesłanki, zasługuje na szczegółowe omówienie, którego tutaj nie podejmuję. Powyższe interpretacje, które z przynajmniej równym powodzeniem, co interpretacja z dnia 13 kwietnia 2015 r., były przedmiotem medialnego zainteresowania, są wskazane w niniejszym tekście ze względu na uwagi dotyczące prostytucji per se, jakie organ poczynił, ustosunkowując się do drugiego wniosku, dotyczącego podatku VAT. Nie tylko odnoszą się one do nowego schematu argumentacyjnego, stoją także w opozycji do opisanej wyżej linii wykładniczej ukształtowanej w przedmiotowym zakresie, co skłania do zastanowienia się nad tym, dlaczego właściwie nierząd jednoznacznie uznawany był dotychczas za czynność, która nie może być przedmiotem prawnie skutecznej umowy, jakie przesłanki determinowały jego występny charakter.

\section{WYMIAR MORALNY PROSTYTUCJI}

\subsection{Godność}

Po pierwsze, moralną dezaprobatę prostytucji łączy się na ogół z pojęciem godności - wprost jest o tym mowa np. we wstępie do Konwencji w sprawie zwalczania handlu ludźmi i eksploatacji prostytucji z dnia 2 grudnia 1949 r., 
gdzie podniesiono, że „prostytucja i towarzyszące jej zło - handel ludźmi w celach prostytucji, są sprzeczne z godnością i wartością człowieka”. Niejednokrotnie, zwłaszcza w opracowaniach pisanych przez prawników, przyjmuje się przy tym, że sprawa jest oczywista, pomijając bardziej szczegółowe uwagi. Czasami wskazuje się na inne wartości, zestawiając je bądź to obok godności (tak np. przy uznaniu, że nierząd jest sprzeczny z poszanowaniem wolności seksualnej), bądź uznając, że stanowią one egzemplifikacje przypadków naruszenia godności (np. poprzez rzeczowe traktowanie bytu ludzkiego). Zauważyć można, że w literaturze prawniczej zdecydowanie dominuje spojrzenie eksponujące zło wyrządzane osobie prostytuującej się, która to perspektywa pomija moralną sytuację klienta. Trudno się temu dziwić, gdy wziąć pod uwagę rażąco nierównomierną intensywność potencjalnych przykrości. Nadto, pozycje te należą niejako do innych sfer, jak ma to miejsce wtedy, gdy prawo karne „oddaje” swoje zwierzchnictwo nad osobą sprawcy teoriom socjologicznym czy resocjalizacyjnym. Należy jednak podkreślić, że w przypadku rozstrzygania o stosunku nierządu do zasad współżycia społecznego pominięcie perspektywy klienta w sposób nieuzasadniony zawęża spektrum rozpatrywanych przypadków.

Problematyka godności osoby prostytuującej się nie jest błaha. Etyk i antropolog rosyjskiego pochodzenia, Igor Primoratz, pisząc o degradacji związanej z prostytuowaniem się, zwraca uwagę na cztery okoliczności, które pojawiają się w ramach tego najczęściej stawianego nierządowi zarzutu: (1) bezosobowy charakter relacji; (2) traktowanie osoby prostytuującej się tylko jako środka; (3) dokonywanie intymnych czynów dla niechwalebnego celu - zysku wyrażanego w pieniądzu; (4) równanie sprzedaży ciała ze sprzedażą człowieka (ludzka istota postawiona zostaje w pozycji „towarowej” służalczości) (Primoratz 2012, 142-150). Myśliciel przedstawia przy tym kontrargumenty, które skupiają się $\mathrm{w}$ istocie na wykazaniu, że takie same zarzuty czynić możemy wobec innych, powszechnie akceptowalnych zachowań. W pierwszej kolejności zauważa, że (ad 1) szereg relacji z drugim człowiekiem ma bezosobowy charakter, podkreślając przy tym, iż osobiste relacje utrzymujemy tylko z małą częścią naszego otoczenia, pisze: ,[n]ie ma nic złego w myśleniu i odnoszeniu się do sprzedawcy gazet jako do sprzedawcy właśnie i nic ponadto" (tamże, 144). Podobnie rozprawia się z drugim argumentem - (ad 2) instrumentalny charakter bilateralnych stosunków międzyludzkich jest powszechną praktyką w sytuacjach, w których każda ze stron zainteresowana jest wymianą dóbr innego rodzaju. Co do trzeciego (ad 3), Primoratz podnosi, że podejmowanie intymnych czynności dla zarobku jest normą choćby dla pielęgniarek zajmujących się higieną intymną niepełnosprawnych pacjentów. Służalczość natomiast nie jest niczym nadzwyczajnym dla kelnera czy fryzjera (ad 4).

Wywód Primoratza uświadamia problematyczność poprzestania na ogólnym sformułowaniu, że prostytucja godzi w godność. O tym, jak pojemne jest to pojęcie, a w związku z tym jak różne można łączyć z nim konsekwencje, dobrze 
świadczy również polemika podejmowana w tym zakresie w środowiskach feministycznych (Witowicz 2001). Z programowego dążenia do emancypacji kobiet i równouprawnienia płci dedukowane są bowiem wnioski, które często stoją do siebie w jawnej opozycji. Z jednej strony prezentowane jest stanowisko ruchów pro-prostytucyjnych - podkreślają one władzę wolnych obywatelek i obywateli nad swoimi ciałami, które to zwierzchnictwo obejmuje również prawo do sprzedawania usług seksualnych. $Z$ drugiej jawią się abolicjonistki, które widzą w nierządzie skutek biedy, będący jednym z przejawów zniewolenia kobiet, koniecznie związany z władzą i przemocą (tamże, 43).

\subsection{Wartości tradycyjne}

Naturalnie, inne próby, tj. abstrahujące od pojęcia godności, są równie dopuszczalne (oczywiście nie każda koncepcja podejmowana w ramach feminizmu musi odwoływać się do tego terminu, niejednokrotnie jednak związek taki, choćby pośrednio, daje się uchwycić). Popularne jest np. wiązanie moralnej dezaprobaty nierządu z postulatem ochrony rodziny czy konkretniej - małżeństwa. Chociaż bowiem skorzystanie $\mathrm{z}$ usług osoby prostytuującej się niekoniecznie jest zdradą, w istotę tego pojęcia wpisane jest to, że spełnia się ono poza małżeństwem. Nie umniejszają temu stwierdzeniu zarzuty, w zgodzie z którymi zawarcie związku małżeńskiego stanowi w praktyce nic więcej niźli zinstytucjonalizowanie umowy o prostytucję, zawartej bezterminowo między dwoma osobami - jak widział to choćby Fryderyk Engels (Engels 1969, 82). Jest to pewnego rodzaju słowne nadużycie, hiperbola podkreślająca aspekt wyzysku, jaki może panować (panuje?) w tradycyjnym modelu rodziny. Nie sposób jednak nie uznać, iż istnieje jakościowa zmiana rzutująca na język i omawiane terminy, której wystapienie wyznaczane jest aktem ślubu. Prostytutka, która podejmuje współżycie seksualne z klientem, z którym wzięła ślub, przestaje uprawiać z nim prostytucję. Co najwyżej powiedzieć można, że jest traktowana bądź wciąż zachowuje się ,jak prostytutka”.

Mając to na uwadze, podnieść trzeba, że żywo obecne w naszej rzeczywistości społecznej przekonania odwołujące się do tradycji chrześcijańskiej zakazują - przynajmniej w sferze postulatów - stosunków seksualnych odbywających się bez ślubu. Niezależnie więc od tego, czy z płatnych usług seksualnych korzysta kawaler, panna, mąż albo żona, bądź też wdowiec czy wdowa, można powiedzieć, że godzą one w wartość rodziny. Co bardziej ortodoksyjni mogą też szukać podstaw dla uzasadnienia podobnego zakazu w związku z wymogiem powstrzymania się od stosunków, które nie służą prokreacji - prostytucja nie jest wszak ukierunkowana na spłodzenie potomstwa. 


\subsection{Aspekt pragmatyczny}

W ten sposób ze sfery religijnej można przejść do sfery pragmatycznej. Źródła moralnego potępienia nierządu da się bowiem uzależnić od negatywnych skutków natury empirycznej - prostytucja sprzyja powstawaniu i przekazywaniu chorób, naraża osoby prostytuujące się na agresję klientów, destabilizuje rodzinę, wystawia na niebezpieczeństwo spotkania się z potępieniem społeczeństwa, dysharmonizuje sferę życia erotycznego osób ją uprawiających. Oczywiście można próbować w sposób prosty odrzucić te i podobne racje, podnosząc, że są to tylko sądy natury opisowej i żadnego zdania powinnościowego wnioskować z nich nie można. $\mathrm{Z}$ tego, że prostytucji często towarzyszy jakiegoś rodzaju patologia, nie wynika logicznie, iż ona sama w sobie jest godna potępienia. Przypomnieć wobec tego należy, że moralna dezaprobata określonego zachowania w omawianym zakresie zachodzi przez pryzmat zasad współżycia społecznego, dla których nie bez znaczenia jest wymiar społeczny (Małecki 2003). Ten zaś wymaga zazwyczaj odniesienia się do nieostrej kategorii pożyteczności, która w takim ujęciu pozwala wypowiadać jakiekolwiek sensowne zdania powinnościowe (Kołakowski 2016, 156-157). W zgodzie z tym nawet gdyby prostytucja w pewnych przypadkach mogła „,nie być zła”, a zarazem nie powodować negatywnych skutków społecznych, to jeśli utylitarystyczny rachunek wskazywałby, że jej potępienie przyczyni się do ogólnego zmniejszenia cierpienia, taka restrykcja byłaby uznana za pożądaną.

\subsection{Pozycja klienta}

Do wyżej wskazanych argumentów, niemających ambicji wyczerpania tematu, a raczej sygnalizujących możliwe sposoby podejmowanych uzasadnień i podkreślających potencjalne kłopoty z nimi związane, dodać należy zaznaczone wcześniej racje odwołujące się do osoby klienta. Choć tradycyjnie krytyka nierządu zwykła w przeważającej mierze skupiać się na osobach prostytuujących się (Primoratz 2012, 129), to nie należy przeoczyć, że korzystanie z takiej usługi może klienta zubażać wewnętrznie, zaś jej aprobata - sygnalizować, iż nie ma nic złego w instrumentalizowaniu istoty ludzkiej (Kant 1971, 20), czyli ostatecznie czynić takiego usługobiorcę człowiekiem gorszym. Dochodzi do tego niebezpieczeństwo społecznych nieszczęść, jakie mogą spotkać taką osobę, jak rozpad małżeństwa, ostracyzm.

Dodatkowo, w świetle niektórych przekonań, stosunek seksualny popełniony z osobą prostytuującą się może czynić ewentualnie pokrzywdzonym dziecko spłodzone w ten sposób. Zachodzić mogą problemy z ustaleniem ojcostwa, zmniejszają się także szanse na spędzenie dzieciństwa w rodzinie o tradycyjnym kształcie - gdy według dominujących wzorców jest to stan najbardziej pożądany. Kwestia ta zahacza o szereg etycznych problemów, których chociażby nakreślenie wykracza poza ramy wywodu. Mało kontrowersyjne jest jednak spostrzeżenie, że 
w zgodzie z niejednym kodeksem etycznym pożądana jest jak najmniejsza liczba dzieci pochodzących z prostytucji - to zaś w praktyce może przyczyniać się do ich zaniżonej samooceny i stanowić źródło cierpień.

\subsection{Argumenty przeciwne}

Z drugiej strony należy wspomnieć o racjach przemawiających za akceptacją nierządu. Wojciech Załuski wymienia tutaj nieuchronność prostytucji (nie sposób jej wyeliminować, a to ze względu na uwarunkowania biologiczne) oraz jej pozytywne skutki społeczne (,kanalizowanie potencjalnie destruktywnego popędu płciowego mężczyzn") (Załuski 2010, 186). Ruchy pro-prostytucyjne dodałyby do tego m.in., że restrykcje o przedmiotowym zakresie ograniczają wolność (Gardian-Miałkowska 2013, 133), w samym zjawisku złe jest tylko jego społeczne potępienie i uprzedzenia, zaś osoby prostytuujące się, podobnie jak przedstawiciele innych zawodów, nie sprzedają swojego ciała, lecz czas (Witowicz 2001, 44).

Podkreślić można znaczenie jednego argumentu, który jest szczególnie istotny, gdy wziąć pod uwagę obwarowanie: „,czynność, która nie może być przedmiotem prawnie skutecznej umowy" - otóż, nie należą do rzadkości przypadki osób, które deklarują, że chcą uprawiać ten zawód. Rozstrzygnięcia w tym zakresie muszą uwzględnić ocenę ich właściwej, tj. „prawdziwej” woli. Tu wypadałaby podjąć dalsze dywagacje - a to np. ustalić, czy takie osoby rzeczywiście (,naprawdę") tego chca, czy może wcale nie chca, ale nie wyobrażają sobie innego sposobu na życie (czy w kapitalizmie nie jest jednak tak, że przytłaczająca większość staje przed podobnym wyborem?). Problem prostytucji w tym świetle przedstawia się w pewnej analogii np. do społecznego potępienia kazirodztwa, tj. można wyobrazić sobie sytuacje, kiedy brak będzie osoby, którą należałoby wskazać jako bezpośrednio pokrzywdzona.

\subsection{Przeciwko autonomii woli}

Kwestia zgody obu stron na zawarcie umowy o prostytucję zahacza w omawianym kontekście o istotny aspekt problemu roli państwa w ogóle. Omawianą tematykę można rozpatrywać przez pryzmat rozważenia dylematu, w jakim zakresie państwo ma zapewniać możliwość realizacji autonomii woli, w jakim zaś stać na straży innych wartości - ludzkiej godności, rodziny, małżeństwa czy porządku społecznego (analizowanego przy uwzględnieniu tych okoliczności, które wymieniane były wyżej w akapicie dotyczącym pragmatycznych argumentów przeciw nierządowi). Zasadne jest swoiste „Zważenie” tych wartości, tj. ustalenie - wobec zachodzącego konfliktu - które są ważniejsze i jako takie zasługujące na ochronę.

Nie tracąc z pola widzenia indywidualnego charakteru wielu przypadków, za właściwe rozwiązanie uznaję przyjęcie, że wymienione w drugiej kolejności wartości, a zwłaszcza ludzka godność i związana z nią cześć, są tymi jakościami, 
które należy uznać za istotniejsze, przeważające nad wymogiem respektowania autonomii woli. $\mathrm{W}$ zgodzie $\mathrm{z}$ tym podejściem zasada swobody umów - a więc bodaj najbardziej uchwytny przejaw tej autonomii - stanowi swoiste lex inferior w stosunku do postulatu ochrony godności. Jakkolwiek bowiem ma ona podstawowe znaczenie dla całej dziedziny prawa cywilnego, to jednak godność nie tylko wynika bezpośrednio z praw człowieka, lecz także stanowi podstawowe pojęcie, wokół którego znaczna część koncepcji dotyczących tych praw jest skupiona. Prawa człowieka natomiast - jak również często się podnosi - mają charakter rudymentarny, hierarchicznie stanowią nieprzekraczalne lex superior, ostatnią z norm dających się ująć w słowa.

Do tego można dodać, że swoboda umów ustępuje tutaj nie przed jedna, ale przed wieloma (wyżej wskazanymi) wartościami, niebagatelnymi z punktu widzenia porządku publicznego. Jest to zagadnienie o tyle problematyczne, że koresponduje ono z treścią niezwykle istotnego art. 33 ust. 3 Konstytucji RP, który stanowi o ograniczeniach $\mathrm{w}$ zakresie korzystania $\mathrm{z}$ konstytucyjnych wolności i praw. Normodawca polski nie ustanowił ustawowego zakazu zawierania umów o prostytucję, z czego wydaje się wynikać, że nie jest on konieczny dla bezpieczeństwa lub porządku publicznego, bądź ochrony moralności publicznej, albo wolności i praw innych osób. Tym samym opisane „ważenie” odbywa się tylko na płaszczyźnie moralnej, do której odsyłają omawiane przepisy ustaw podatkowych. Jesteśmy tedy niejako skazani na niepewność. Eskalacja znaczeniowa pojęcia wolności prowadziłaby zapewne do wykładni o rezultacie zgoła przeciwnym. Doniosły jest tutaj wymiar społeczny - choć brak poparcia dla tego twierdzenia w postaci badań socjologicznych, wydaje się, że stanowisko powyższe znajduje powszechną niemal aprobatę (dowodem może być zasadnicza zgodność doktryny i orzecznictwa).

\subsection{Podejście empiryczne}

W zgodzie z powyższym, usprawiedliwieniem dla uznania prostytucji za czynność, która nie może być przedmiotem prawnie skutecznej umowy, może być rozwiązanie stricte empiryczne. W odróżnieniu do opisanego w punkcie 4.3 aspektu pragmatycznego potępienia prostytucji, brak w takim przypadku bezpośredniego odniesienia do sądów o charakterze powinnościowym. Podejście takie polega na dokonaniu aktu pewnego rodzaju ideologicznej, moralnej i doktrynalnej kapitulacji, opierającego się na przejściu do sfery ściśle empirycznej i orzeczeniu na tej podstawie, że skoro dominuje w naszym kraju pogląd, w zgodzie z którym prostytucja jest moralnie naganna, to nie można jej pogodzić z zasadami współżycia społecznego. Zasady te rozumiane są tutaj raczej potocznie, bez bagażu intelektualnego, jaki na gruncie tej klauzuli generalnej wypracowali prawnicy, a nawet więcej - bez uzasadnienia moralnego innego niż takie, które odnosi się do niejasnej kategorii intuicji. Choć można logicznie podważać takie wynikanie, 
jego siła perswazyjna jest niebagatelna. Podejście to odwraca schemat argumentacyjny: to nie z zasad współżycia społecznego wynika, że prostytucja jest potępiana, ale przez to, że jest potępiana, stoi z tymi zasadami w sprzeczności.

Argument ten musi uwzględniać opisywany społeczny aspekt. Być może postępująca sekularyzacja i związana z nim „liberalizacja” obyczajowości seksualnej doprowadzi do istotnych zmian. Nie bez znaczenia jest tutaj wymiar europejski - nie tylko polski porządek prawny musi uwzględniać konieczność dostosowywania się do panujących we Wspólnocie rozwiązań. Mając na uwadze, że w części krajów Unii Europejskiej umowy o prostytucję są objęte władztwem państwa, nie sposób pominąć możności ich wpływu na obyczajowość powszechnie dzieloną w naszym kraju. To jednak perspektywa wieloletnia, którą trudno przewidzieć.

\subsection{Skuteczność czynności prawnej}

Wracając do przytaczanej interpretacji indywidualnej z zakresu podatku VAT, należy się odnieść do argumentacji Ministra Finansów, który przy powoływaniu się na odpowiednią literaturę, przekonywał do stanowiska, że umowa z osobą prostytuującą się jest (a) jednostronnie zobowiązująca albo też (b) staje się ważna po wykonaniu usługi. Organ wyciagał stąd wniosek, że umowa taka nie musi być sprzeczna z zasadami współżycia społecznego, a tym samym może nie zachodzić nieważność czynności prawnej. Nawet gdy zgodzimy się z przytoczonym poglądem (Księżak 2014), rozumowanie organu wciąż trzeba będzie uznać za niepoprawne.

Przyjęcie, że umowa o prostytucję staje się ważna po wykonaniu usługi (ad b), zawiera założenie, iż przed jej wykonaniem jest to umowa nieważna (następuje tu konwalidacja). Choć Paweł Księżak wprost o tym nie wspomina, chodzi zapewne o nieważność, która jest konsekwencją sprzeczności z zasadami współżycia społecznego (art. 58 § 2 k.c.). Mimo że prostytucja godzi w porządek moralny wyznaczany tymi zasadami, jednocześnie wynika też z nich, iż wykonanie umowy skutkuje koniecznością uznania ważności umowy i związanych z nimi skutków prawnych. W drugim przypadku (a) wymóg ważności wydaje się przysługiwać takim kontraktom od początku. W tym ujęciu akt prostytucji nie jest czynnością, która nie może być przedmiotem prawnie ważnej umowy, czy prościej - unikając negacji - prostytucja jest czynnością, która może być przedmiotem prawnie ważnej umowy.

Zauważyć należy, że stanowisko organu pomija, iż w omawianych przepisach ustaw podatkowych brak przesłanki bezpośrednio opierającej się na stwierdzeniu ważności umowy, czy nawet jej zgodności z zasadami współżycia społecznego. Zarówno art. 2 ust 1 pkt 4) u.p.d.o.f., jak i art. 6 pkt 2 ustawy o VAT odwołują się do przesłanki skuteczności umowy. Minister Finansów nie zwraca uwagi na funkcjonujące w literaturze rozróżnienie między nieważnością a skutecznością umowy, stawiając między nimi znak równości. Choć kwestia ich wzajemnego stosunku jest 
przedmiotem doktrynalnych sporów, nie jest szczególnie kontrowersyjne stanowisko, w zgodzie z którym pojęcie skuteczności, które pojawia się w obu ustawach, odwołuje się do możliwości zastosowania przymusu państwowego, jaki służyć ma urzeczywistnianiu treści stosunku prawnego (Sobolewski 2009, 25).

Wydaje się tymczasem godzić w intuicje moralne powszechnie dzielone w naszym społeczeństwie pogląd, zgodnie z którym państwo może swoim działaniem bezpośrednio aprobować umowy o prostytucję. Czym innym jest konieczne - a to ze względu na ludzką naturę - przemilczanie obecności nierządu w rzeczywistości społecznej, zaś czym innym jego afirmowanie. Nawet jeśli zgodzić się z poglądem, że spełnienie aktu prostytucji będzie czyniło umowę ważną (b), nie sposób zasadnie oczekiwać, by sąd mógł wydać orzeczenie zobowiązujące dłużnika do oddania swojego ciała wierzycielowi celem dokonania czynności o charakterze seksualnym. Podobnie rzecz ma się przy przyjęciu, że jest to umowa jednostronnie zobowiązująca (a) - jej charakter oczywiście wyklucza taką możliwość.

Wskazać trzeba, że stanowisko to może być skutecznie kontestowane, gdy wziąć pod uwagę możliwe relacje między ważnością a skutecznością. Wobec tego należy podkreślić raz jeszcze, że regulacja ustaw podatkowych odsyła do przesłanki skuteczności, a nie nieważności. Doktryna i orzecznictwo dostrzega w kontekście przepisów u.p.d.o.f. oraz ustawy o VAT przedmiotowe odróżnienie - zauważa się na przykład, że umowy nieważne ze względu na niedochowanie wymaganej formy nie są objęte omawianymi wyłączeniami (Krywan 2014, 87).

Istotne wydaje się tutaj przypomnienie, iż gruntem omawianych zagadnień jest prawo podatkowe, które rządzi się pewną autonomią. Mając na uwadze odmienność i niezależność norm prawa podatkowego i cywilnego, należy pamiętać, że „powstanie skutków prawnopodatkowych jest niezależne od skutków, jakie wywołują te same zdarzenia lub czynności w obszarze regulacji cywilnoprawnych" (Hanusz 2000, 68). Ważność umowy o prostytucję, jej uzależnienie od tego, czy świadczenie zostało spełnione czy nie, są irrelewantne z punktu widzenia prawa podatkowego. Art. 2 ust. 1 pkt 4) u.p.d.o.f. oraz art. 6 ust. 2 ustawy o VAT odnoszą się do abstrakcyjnych stanów i są niezależne od tego, czy w przypadku wykonania umowy o prostytucję ta strona, która otrzymała świadczenie pieniężne, winna je zwrócić.

Skoro ustawodawca posłużył się terminem ,skuteczność”, przenoszenie komplikacji prawnych, które w jego obrębie występują na gruncie piśmiennictwa cywilistów, może stanowić zabieg zbędny, zaś wystarczająco wydolną wskazówką dotyczącą należytej wykładni sformułowania „,czynności, które nie mogą być przedmiotem prawnie skutecznej umowy” jest odpowiedź na pytanie: „czy można, w ramach zastosowania przymusu państwowego, zobowiązać do spełnienia świadczenia o treści określonej tą umową?". Nie chodzi tutaj o kategoryczne uniknięcie odniesienia do prawa cywilnego - byłoby ono oczywiście niezasadne ze względu na terminy, które w obu artykułach zawarto. Chodzi o wskazywaną wyżej okoliczność - niemożność zastosowania władczej presji państwa w stosunku 
do zachowania, które może jednak zostać wtórnie zaakceptowane ze względu na nowe racje, jakie pojawiają się wraz ze spełnieniem świadczenia.

$\mathrm{W}$ tym aspekcie podnoszony często $\mathrm{w}$ dyletanckich rozważaniach na temat opodatkowania prostytucji argument nabiera odpowiedniej siły - faktycznie bowiem uznanie skuteczności umowy o prostytucję, prowadzące do stwierdzenia możności egzekwowania obowiązku spełnienia świadczenia przez obie ze stron przy użyciu aparatu władzy, stawiałoby państwo w pozycji sutenera.

\section{KWESTIE PRAKTYCZNE BRANE POD UWAGE W TOKU POSTĘPOWAŃ PODATKOWYCH}

Przedstawione wyżej uwagi podejmują stosunkowo skromny zakres potencjalnych problemów i abstrahują od szeregu kwestii, z którymi w praktyce należy mierzyć się w postępowaniach, w których podatnicy powołują się na zyski z nierządu. Oczywistym natomiast jest, że w toku takich spraw niewystarczające jest samo powołanie się na przedmiotową okoliczność. Chociaż co do zasady to organy podatkowe muszą podejmować wszelkie niezbędne działania w celu dokładnego wyjaśnienia stanu faktycznego, to - jak wskazuje się w orzecznictwie - z lektury art. 122 oraz art. 187 o.p. wynika, że obowiązek ten doznaje wyjątków, zwłaszcza wtedy, gdy twierdzenia strony w zakresie ustaleń co do stanu faktycznego nie znajdują oparcia w zebranym przez organ materiale dowodowym lub gdy podatnik zaprzecza dokonanej przez organ ocenie stanu faktycznego, podważając jego poprawność (wyrok Wojewódzkiego Sądu Administracyjnego w Gdańsku z dnia 15 września 2015 r., sygn. akt I SA/Gd 387/15). Strona, której zależy na przekonaniu do swoich racji, musi w takim przypadku niejako przejąć inicjatywę.

W sytuacji powoływania się na nierząd sprawa dodatkowo komplikuje się, gdy wziąć pod uwagę zmiany, jakie weszły w życie od dnia 1 stycznia 2016 r. w zakresie postępowań dotyczących przychodów nieznajdujących pokrycia w ujawnionych źródłach lub pochodzących ze źródeł nieujawnionych. Od tego dnia bowiem, w zgodzie z nowo przyjętym art. 2 ust. 6 u.p.d.o.f., w przypadku braku przeciwnego dowodu przyjmuje się, że przychody pochodzą z czynności, które mogą być przedmiotem prawnie skutecznej umowy.

Trudno nie zauważyć, że powołanie się na zyski z nierządu ma osobliwy charakter. Jak stwierdził NSA w przytaczanym wyroku z dnia 7 kwietnia 1995 r., w toku takich spraw organ podatkowy „winien mieć również na uwadze szczególny charakter tego oświadczenia, które [...] może wywierać daleko idące negatywne skutki tak dla osoby składającej to oświadczenie, jak również dla jej rodziny i osób jej bliskich". Takie działanie, z zachowaniem odpowiednich proporcji, porównać można do postępowań w sprawach gwałtu. W obu przypadkach wkraczamy w sferę szczególnej intymności, w której dozór państwa winien być obwarunkowany swoistą wrażliwością, tak aby działając w literze prawa, nie czynić nikomu niepotrzebnej krzywdy. 
Nie tylko jednak niewątpliwie szczególny charakter prowadzonego postępowania dowodowego (wyjątkowy zwłaszcza na tle powszedniej praktyki organów podatkowych) nastręcza problemów. Dochodzą do tego ustalenia o ściśle materialnoprawnym charakterze. Wobec braku ustawowej definicji prostytucji - a ta przecież też nie załatwiałaby sprawy, chodzi przecież o czynność, która nie może być przedmiotem prawnie skutecznej umowy - konieczne jest bowiem choćby rozstrzygnięcie, czy ustalony w toku postępowania stan faktyczny odpowiada nierządowi, czy analizowane zachowanie nie stanowi np. sponsoringu, który zdaniem sądów nie jest wyłączony spod opodatkowania. Wojewódzki Sąd Administracyjny w Gorzowie Wielkopolskim (wyrok z dnia 17 lipca 2013 r., sygn. akt I SA/ Go 299/13) wskazał na przykład, że nie można utożsamiać łożenia przez stałego i wieloletniego partnera z rodzajem nierządu. Wojewódzki Sąd Administracyjny w Gliwicach (wyrok z dnia 21 sierpnia 2012 r.) podkreślił natomiast doniosłość zwieńczenia relacji skarżącej (która powoływała się na nierząd względem partnera) związkiem małżeńskim. Przekazywanie środków finansowych w długoletnim związku partnerskim, po wzięciu pod uwagę charakteru więzi między partnerami, może być kwalifikowane jako darowizna (wyrok Wojewódzkiego Sądu Administracyjnego w Poznaniu z dnia 18 lipca 2012 r., sygn. akt I SA/Po 886/11). Warto zwrócić uwagę, że w ostatniej sprawie skarżąca współtworzyła ów związek $\mathrm{z}$ księdzem. Zadać sobie można $\mathrm{w}$ tym kontekście teoretyczne pytanie, czy sama okoliczność bycia osobą duchowną wpływa na zakres moralnej oceny dokonywanych przysporzeń pieniężnych, tj. ich sprzeczności lub niesprzeczności z zasadami współżycia społecznego.

Samo udowodnienie faktu czerpania zysku z nierządu również nie kończy problemów. W sprawach dotyczących przychodów nieznajdujących pokrycia w ujawnionych źródłach lub pochodzących ze źródeł nieujawnionych konieczne jest bowiem także określenie kwoty, jaką w rzeczywistości można było w ten sposób osiagnąć. W przypadku zysków osiagniętych w krajach, w których przychód pochodzący z prostytucji podlega podatkowi, należy się liczyć z wystąpieniem polskich organów podatkowych do ich zagranicznych odpowiedników z prośbą o stosowne informacje. Organy poddają również ocenie charakter świadczonych usług, to, czy można przypisać im etykietę luksusowych, po to, by kolejno ocenić szanse uzyskania w ten sposób odpowiedniej kwoty (wyrok Wojewódzkiego Sądu Administracyjnego w Olsztynie z dnia 11 października 2012 r., sygn. akt I SA/Ol 385/12).

\section{PODSUMOWANIE}

Rozrachunek z przedstawionych wyżej wywodów jest następujący:

1. Stanowisko organów podatkowych, sądów administracyjnych oraz doktryny co do uznania prostytucji za czynność, która na gruncie podatkowym nie może być przedmiotem prawnie skutecznej umowy jest niemal jednolite. 
2. Uwzględnienie wymiaru społecznego przekonuje do uznania słuszności takiego podejścia.

3. Przedstawione w interpretacji z dnia 7 stycznia 2015 r. (IBPP2/443-987/14/ IK) stanowisko Dyrektora Izby Skarbowej w Katowicach w zakresie uznania prostytucji za czynność, która może być przedmiotem prawnie skutecznej umowy, jest nieprawidłowe.

4. Praktyka postępowań organów podatkowych w sprawach dotyczących powoływania się na nierząd jako źródło zysku uwzględnia m.in. odniesienie się do takich kwestii, jak (a) odróżnienie prostytucji od sponsoringu oraz (b) możność uzyskania przez osoby prostytuujące się kwot określonej wysokości.

\section{BIBLIOGRAFIA}

Berlin, Isaiah. 2004. „O dążeniu do ideału”. Tł. Maciej Tański. W Pokrzywione drzewo człowieczeństwa. Red. Henry Hardy. Tł. Magda Pietrzak-Merta, Maciej Tański. Warszawa: Prószyński i S-ka.

Engels, Fryderyk. 1969. „Pochodzenie rodziny, własności prywatnej i państwa”. Tł. Ludwik Krzywicki. W Fryderyk Engels, Karol Marks. Dzieła. T. 21. Warszawa: Książka i Wiedza.

Gardian-Miałkowska, Renata. 2013. „(Nie)bezpieczeństwo świadczenia usług seksualnych. Świadomość ryzyka i konsekwencji pracy w sex-biznesie na przykładzie doświadczeń mężczyzn uwikłanych w prostytucję". Profilaktyka Społeczna i Resocjalizacja 22: 131-152.

Hanusz, Antoni. 2000. „W kwestii autonomii prawa podatkowego”. W Prawo finansowe i nauka prawa finansowego na przełomie wieków. Red. Apoloniusz Kostecki. Kraków: Kantor Wydawniczy Zakamycze.

Kant, Immanuel. 1971. Uzasadnienie metafizyki moralności. Tł. Mścisław Wartenberg. Warszawa: PWN.

Kołakowski, Leszek. 2016. „Trwałość dylematu »Sein-Sollen«”. Przeglą Polityczny 135: 145-166.

Krywan, Tomasz. 2014. VAT. Komentarz 2014. Wrocław: Oficyna Wydawnicza „Unimex”.

Księżak, Paweł. 2014. „Komentarz do art. 58 Kodeksu cywilnego”. W Kodeks cywilny. Część ogólna. Komentarz. Wyd. 2. Red. Małgorzata Pyziak-Szafnicka, Paweł Księżak. Warszawa: Lex a Wolters Kluwer business.

Kuc, Marek. 2015. „Prostytucja sposobem na uniknięcie płacenia podatków”. http://www.serwis prawa.pl/artykuly, 10288,26584,prostytucja-sposobem-na-unikniecie-placenia-podatkow [dostęp 23.08.2016].

Malinowski, Michał. 2015. „PIT: prostytucja pomoże »wywinąć się« z nieujawnionych przychodów". http://www.podatki.abc.com.pl/czytaj/-/artykul/pit-prostytucja-pomoze-wywinac-sie-z-nieujawnionych-przychodow [dostęp 23.08.2016].

Małecki, Jerzy K. 2003. „Komentarz do art. 2 ustawy o podatku dochodowym od osób fizycznych”. W Andrzej Gomułowicz, Jerzy Małecki. Ustawa o podatku dochodowym od osób fizycznych. Komentarz. Warszawa: Dom Wydawniczy ABC.

Molga, Tomasz. 2015. „Polska prostytutka wygrała z fiskusem. Pokazała zdjęcia, cennik, recenzje i uratowała oszczędności z 9 lat”. http://natemat.p1/157365,polskie-prostytutka-wygrala-z-fiskusem-pokazala-zdjecia-cennik-recenzje-i-uratowala-oszczednosci-z-9-lat [dostęp 23.08.2016].

Pietrzykowski, Krzysztof. 2015. „Objaśnienia do art. 5”. W Kodeks cywilny. T. 1. Komentarz. Art. 1-449 ${ }^{10}$. Red. Krzysztof Pierzykowski. Warszawa: C.H. Beck.

Pogroszewska, Monika. 2015. „Prostytucja sposobem na legalizację pieniędzy”. http://www.rp.pl/ artykul/1201206-Prostytucja-sposobem-na-legalizacje-pieniedzy.html\#ap-2 [dostęp 23.08.2016]. 
Primoratz, Igor. 2012. Filozofia seksu. Tł. Joanna Klimczyk. Warszawa: Wydawnictwo Naukowe PWN.

Radwański, Zbigniew. 2004. Prawo cywilne - czesść ogólna. Warszawa: C.H. Beck.

Sobolewski, Przemysław. 2009. „Kompetencja do dokonania czynności prawnej jako przesłanka jej prawnej doniosłości". Przeglad Prawa Handlowego 2 (198): 24-33.

Strzelec, Dariusz. 2014. „Komentarz do art. 2”. W Komentarz do ustawy o podatku dochodowym od osób fizycznych. Red. Adam Mariański, Włodzimierz Nykiel. Gdańsk: Ośrodek Doradztwa i Doskonalenia Kadr.

Witowicz, Bożena. 2001. „Feminizm wobec prostytucji”. Prawo i Pteć 3: 41-45.

Załuski, Wojciech. 2010. „Aspekty seksualności”. W Paradoksy bioetyki prawniczej. Red. Bartosz Brożek, Marta Soniewicka, Jerzy Stelmach, Wojciech Załuski. Warszawa: Oficyna a Wolters Kluwer business.

\author{
Akty prawne \\ Konwencja w sprawie zwalczania handlu ludźmi i eksploatacji prostytucji z dnia 2 grudnia 1949 r. \\ (ratyfikowana przez Polskę na podstawie ustawy z dnia 29 lutego 1952 r., Dz. U. 1952, Nr 13, \\ poz. 78). \\ Ustawa z dnia 23 kwietnia 1964 r. - Kodeks cywilny (t.j. Dz. U. 2017, poz. 459 ze zm.). \\ Ustawa z dnia 16 grudnia 1972 r. o podatku dochodowym (Dz. U. 1972, Nr 53, poz. 338, 339). \\ Ustawa z dnia 26 lipca 1991 r. o podatku dochodowym od osób fizycznych (t.j. Dz. U. 2017, \\ poz. 859 ze zm.). \\ Ustawa z dnia 29 sierpnia 1997 r. - Ordynacja podatkowa (t.j. Dz. U. 2015, poz. 613 ze zm.). \\ Ustawa z dnia 11 marca 2004 r. o podatku od towarów i usług (t.j. Dz. U. 2017, poz. 379 ze zm.).
}

\title{
Adam Olczyk
}

\section{PROSTITUTION AS AN ACT NOT SUBJECT TO TAXATION IN POLISH LAW}

\begin{abstract}
The aim of this publication is to bring closer legal regulations referring to the statement that prostitution does not constitute income subject to tax in Polish law. This notion has been frequently presented by administrative courts and tax authorities - and this issue is discussed in the first part of the article. The next one focuses on legal articles that regulate this tax exemption. In this unit the author also describes the individual tax interpretation published in a case of socalled virtual prostitution. Third part concerns a moral aspect of sex acts in exchange for payment as well as possible ways of argumentation in such cases. At the end the author presents practice of arrangements that the Polish tax authorities pursue to establish if a taxpayer really engages sexual relations for financial benefits (like distinction between prostitution and donation).

Keywords: prostitution, tax, individual tax interpretation, morality, legally effective legal transaction.
\end{abstract}

